$80 \%$ of the women appreciated having someone to listen to their problems; there was little change in the physical outcome of the pregnancy. ${ }^{21}$ In addition, I suspect that midwives and doctors are haunted by the fear that they might miss something (or at least be accused of missing something) if they don't conform to the expected ritual.

Current moves to demedicalise and decentralise childbirth, potentially providing more continuity of care, are necessitating radical changes in the organisation of maternity care..$^{22}$ They should be seen as an opportunity to discard outdated rituals, rather than simply to transfer them from doctors to midwives. The time saved could be channelled into prospective trials of more promising interventions, such as programmes of smoking cessation, and increasing the time available for training in counselling about the many new screening tests becoming available in early pregnancy.

PHILIP STEER

Professor and head

Academic Department of Obstetrics and Gynaecology,

Charing Cross and Westminster Medical School,

London SW $109 \mathrm{NH}$

1 Bull MJV. Maternal and fetal screening for antenatal care. BMF 1990;300:1118-20

2 Coope JK, Scott AV. A programme for shared maternity and child care. BMf 1982;284:1936-7.

3 Marsh GN. New programme of antenatal care in general practice. $B M \mathcal{F} 1985 ; 291: 646-8$.
4 Van der Spuy Z, Steer PJ, McCusker M, Steele SJ, Jacobs HS. Outcome of pregnancy in underweight women after spontaneous and induced ovulation. $B M Y$ 1 1988;296:962-5.

5 Seidman DS, Ever-Hadani P, Gale R. The effect of maternal weight gain in pregnancy on birth weight. Obstet Gynecol 1989;74:240-6.

6 Abrams BF, Laros RK. Prepregnancy weight, weight gain, and birth weight. Am $\mathcal{f}$ Obstet Gynecol 1986;154:503-9.

7 Parker JD, Abrams B. Prenatal weight gain advice: an examination of the recent prenatal weight gain recommendations of the Institute of Medicine. Obstet Gynecol 1992;79:664-9.

8 Dawes MG, Green J, Ashurst H. Routine weighing in pregnancy. BMf 1992;304:487-9.

9 Backe B, Nakeling J. Effectiveness of antenatal care: a population based study. $\mathrm{Br} f$ Obstet Gynaecol 1993;100:727-32.

10 Danielian PJ, Allman ACJ, Steer PJ. Is obstetric and neonatal outcome worse in fetuses who fail to reach their own growth potential? Br 7 Obstet Gynaecol 1992;99:452-4.

11 Soothill PW, Ajayi RA, Campbell SH, Nicolaides KH. Prediction of morbidity in small and normally grown fetuses by heart rate variability, biophysical profile score and umbilical artery normally grown fetuses by heart rate variability, bio

12 Lind T, Hytten FE. The excretion of glucose during normal pregnancy. $\mathcal{f}$ Obstet Gynaecol B Commonw 1972;79:961-5.

13 Gillmer MDG, Oakley NW, Beard RW, Nithyananthan R, Cawston M. Screening for diabetes during pregnancy. Br $\mathcal{F}$ Obstet Gynaecol 1980;87:377-82.

14 Campbell-Brown M, McFadyen IR, Seal DV, Stephenson ML. Is screening for bacteriuria in pregnancy worthwhile? $B M \mp$ 1987;294:1579-82.

15 Perry IJ, Gosling P, Sanghera K, Churchill D, Luesley DM, Beevers DG. Urinary microalbumi excretion in early pregnancy and gestational age at delivery. $B M F$ 1993;307:420-1.

16 Sharif $\mathrm{K}$, Whittle $\mathrm{M}$. Routine antenatal fetal heart rate auscultation: is it necessary? $\mathcal{f}$ Obstet Gynaecol 1993;13:111-3.

17 Grant A, Elbourne D, Valentin L, Alexander S. Routine formal fetal movement counting and risk f antepartum late death in normally formed singletons. Lancet 1989;ii:345-9.

$18 \mathrm{Hall}$ MH, Chng PK, MacGillivray I. Is routine antenatal care worthwhile? Lancet 1980;i:78-80.

19 Spencer B, Thomas H, Morris J. A randomised controlled trial of the provision of a social support service during pregnancy: the South Manchester family worker project. Br $\mathcal{f}$ Obstet Gynaecol 1989;96:281-8.

20 Konte JM, Creasy RK, Laros RK. California north coast preterm birth prevention project. Obstet Gynecol 1988;71:727-30.

21 Oakley A, Rajan L, Grant A. Social support and pregnancy outcome. Br $f$ Obstet Gynaecol 1990;97:155-62.

22 Lilford R. Midwives to manage uncomplicated childbirth. BMf 1993;307:339-40.

\title{
The routine six week postnatal vaginal examination
}

\author{
Forget it
}

We have been schooled to believe that routine postnatal vaginal examinations at six weeks are necessary, and current obstetric and midwifery textbooks perpetuate this teaching. We are told how to examine for supposed abnormalities and what correction may or may not be needed. This advice is based on supposition and has now been challenged. Strube pointed out that this routine vaginal examination is illogical. ${ }^{1}$ Bowers found that women viewed discussion concerning their baby and how they felt and contraceptive advice as more important than a physical examination. ${ }^{2}$

Sharif $e t$ al studied the case records of 150 women attending their doctor for postnatal checks. ${ }^{3}$ Although only 25 had a specific indication, they all had a vaginal examination. An "abnormality" was found in only six of the 125 women who had a routine examination without any specific indication: three had an asymptomatic "bulky" uterus and three had cervical ectopy. None of these patients had any treatment.

Some doctors and midwives recommend that women should not have sexual intercourse until after the routine vaginal examination at six weeks but most women resume sexual intercourse before the postnatal visit-usually between two and four weeks after birth. ${ }^{45}$ Some women experience discomfort or bleeding from their vaginal or perineal wounds, but they do not experience important harm.

Some women may have been conditioned to think that a vaginal examination is important, but most see it as a necessary evil rather than a helpful experience. ${ }^{6}$ The examination consumes resources, requires a chaperone for male doctors, and uses time that would be better spent on counselling; it should therefore be done only when a specific indication exists. These are mostly obvious and include abnormal discharge and dyspareunia. Women wanting reassurance and those who wish to combine their postnatal visit with the insertion of an intrauterine device or a repeat cervical smear test should also be examined. In addition, those few women complaining of stress incontinence should be examined, mainly to ensure that their endeavours to exercise and strengthen the pelvic floor muscles are directed at the right set of muscles.

The postnatal visit at six weeks is an important opportunity to consider more general disorders such as backache and depression and to discuss infant feeding and immunisation and contraception. Ideally, at these visits the women would see both the general practitioner and the community midwife. A few patients (those with serious complications of pregnancy or childbirth, resulting in serious illness or death of the baby) should also see their consultant obstetrician at this time. Women who were delivered by caesarean section for the first time would benefit from seeing a consultant, who could arrange $x$ ray pelvimetry or computed tomography of the pelvis to improve advice regarding the desirable mode of any future deliveries.

The postnatal visit at six weeks is an important tradition that should continue. But the emphasis should change, with vaginal examination being limited to women with specific indications.

TONY NOBLE

Royal Hampshire County Hospital,

Winchester,

Hampshire SO22 5DG

1 Strube G. A woman's health. London: Croom Helm, 1980.

2 Bowers J. Is the six-weeks postnatal examination necessary? Practitioner 1985;229:1113-5.

3 Sharif $\mathrm{K}$, Clarke $\mathrm{P}$, Whittle $M$. Routine six weeks postnatal vaginal examination: to do or not to do? 7 Obstet Gymaecol 1993:13:251-2.

f Obstet Gynaecol 1993;13:251-2. Am f Obstet Gynecol 1976;126:41 6-7.



6 Swaffield L. Today's mother. Nursing Times 1983 Mar 9:59-60. 